\title{
PENGARUH BERAT BADAN INDUK TERHADAP BERAT LAHIR DAN PERTAMBAHAN BOBOT BADAN PEDET PADA SAPI BALI YANG DIPELIHARA SECARA SEMI-INTENSIF DI KABUPATEN BELU
}

\author{
${ }^{1)}$ Jenitha Verawati Fallo, ${ }^{2)}$ Enike Dwi Kusumawati, ${ }^{3)}$ Aju Tjatur Nugroho Krisnaningsih \\ ${ }^{1,2,3}$ Fakultas Peternakan; Universitas Kanjuruhan Malang \\ nitafallo02@gmail.com
}

\begin{abstract}
Abstrak
Tujuan penelitian ini untuk mengetahui pengaruh berat badan induk terhadap berat lahir dan pertambahan bobot badan pedet pada sapi Bali yang dipelihara secara semi-intensif. Materi yang digunakan dalam penelitian ini adalah 30 ekor induk sapi Bali dengan umur 3-5 tahun dan 30 ekor pedet sapi Bali dari tahun 2015 sampai 2017. Metode yang digunakan dalam penelitian ini adalah metode kuantitatif dengan analisis data dari data recording, dengan 3 perlakuan yaitu P1 bobot badan $151-200 \mathrm{Kg}$, P2 bobot badan 201-250 Kg, P3 bobot badan 251-300 Kg dengan masing-masing perlakuan di ulangan 10 kali. Variabel yang diukur adalah berat lahir sapi Bali dan pertambahan bobot badan harian, data dianalisa menggunakan analisa varian.Hasil dari penelitian ini menunjukkan bahwa berat badan induk tidak memberikan pengaruh yang nyata terhadap berat lahir dan pertambahan bobot badan pedet pada sapi Bali yang dipelihara secara semi-intensif $(\mathrm{P}>0,05)$, dengan berat lahir pedet tertinggi $20 \mathrm{Kg}$ pada kelompok bobot badan induk $251-300 \mathrm{Kg}$, demikian pula pada kelompok bobot badan induk 251-300 Kg pertambahan bobot badan pedet tertimggi adalah 0,87 Kg. Berdasarkan hasil penelitian ini dapat disimpulkan bahwa berat lahir dan pertambahan bobot badan pedet pada sapi Bali tidak dipengaruhi oleh berat badan induk pada sistem pemeliharaan semi-intensif.

Kata kunci: sapi bali, berat lahir, pertambahan bobot badan
\end{abstract}

\begin{abstract}
The purpose of this study was to determine the effect of maternal weight on birth weight and calf weight gain in semi-intensive Balinese cattle.The material used in this study were 30 Balinese cows with 3-5 years of age and 30 Balinese calves from 2015 to 2017. The method used in this study was a quantitative method by analyzing data from recording data, with 3 treatments namely P1 body weight $151-200 \mathrm{Kg}, \mathrm{P} 2$ body weight $201-250 \mathrm{Kg}, \mathrm{P} 3$ body weight $251-300 \mathrm{Kg}$ with replication is not the same, namely 10 replications. The variables measured were Bali cattle birth weight and daily body weight gain and analyzed the data using a completely randomized design. The results of this study indicate that maternal body weight did not have a significant effect on birth weight and calf weight gain in semi-intensive Balinese cattle $(\mathrm{P}>0.05)$, with the highest calf birth weight $20 \mathrm{Kg}$ in the body weight group the main $251-300 \mathrm{Kg}$, as well as the parent body weight $251-300 \mathrm{Kg}$ the highest increase in calf body weight was $0.87 \mathrm{Kg}$. Based on the results of this study it can be concluded that birth weight and calf weight gain in Balinese cattle are not influenced by the body weight of the semiintensive maintenance system.

Keywords: Bali Cattle, Maternal, Birth Weight, Weight gain.
\end{abstract}

\section{Pendahuluan}

Kabupaten Belu merupakan salah satu Kabupaten yang berusaha mengembangkan sapi Bali. Besarnya apresiasi dari pihak birokrasi dan masyarakat serta iklim yang mendukung untuk menjadikan sentrum pengembangan sapi Bali. Pengembangan sektor peternakan di Kabupaten Belu mendapat perhatian dari pemerintah, terbukti dengan ditetapkannya Kabupaten Belu dalam program Inseminasi Buatan (IB) dalam 
sektor peternakan. Kabupaten Belu memiliki iklim dan letak geografis yang menguntungkan. Disamping itu potensi lahan yang luas untuk pengembangan sektor ini masih luas dan tersedianya pakan yang melimpah merupakan salah satu indikator dipilihnya Kabupaten Belu dalam pengembangan program di sektor Peternakan.

Sapi Bali merupakan sapi pedaging asli Indonesia dan merupakan hasil domestikasi dari Banteng (Bos-bibos banteng) (Siregar, 2006), dan sapi asli pulau Bali (Sutan, 2004). Sapi Bali menjadi primadona sapi pedaging di Indonesia karena mempunyai kemampuan reproduksi tinggi, serta dapat digunakan sebagai ternak kerja di sawah dan ladang (Putu dkk., 2008), persentase karkas tinggi, daging tanpa lemak, heterosis positif tinggi pada persilangan (Pane, 2000), daya adaptasi yang tinggi terhadap lingkungan dan persentase kelahiran dapat mencapai 80 persen (Tanari, 2001).

Induk sapi Bali merupakan hal yang harus diperhatikan dalam usaha meningkatkan populasi dan produktivitas dalam peternakan sapi potong/pedaging. Induk sapi Bali akan mengawini pejantan sehingga terjadi kebuntingan dan menghasilkan pedet yang baru. Bobot lahir merupakan salah satu hal penting dalam pola pertumbuhan karena anak sapi dengan bobot yang lebih besar dari rataan dan lahir normal mampu mempertahankan hidup.

Bobot lahir merupakan faktor yang penting dalam pertumbuhan pedet, sapi dengan bobot lahir yang besar dan lahir secara normal akan lebih mampu mempertahankan kehidupannya. Bobot lahir anak sapi Bali adalah 18,4 $\pm 1,6 \mathrm{Kg}$. Bobot lahir antara pedet jantan dan pedet betina sangat bervariasi. Kisaran bobot lahir pedet jantan antara 10,5-22 $\mathrm{Kg}$ dengan rata-rata $18,9 \pm 1,4 \mathrm{Kg}$. Sementara pedet betina memiliki kisaran bobot lahir antara 13-26 Kg dengan rataan $17,9 \pm 6 \mathrm{Kg}$ (Prasojol dkk, 2010). Bobot lahir juga tidak terlepas dari pengaruh induk dimana hanya induk yang berkualitas yang dapat menghasilkan berat lahir yang tinggi. Penurunan produktivitas ternak diduga disebabkan oleh tingkat kebuntingan dan tingkat kelahiran (berat lahir) yang semakin rendah.

Selain itu pertambahan bobot badan juga sangat mempengaruhi pertumbuhan pedet sapi tersebut, dimana pertambahan bobot badan merupakan perubahan ukuran tubuh yang meliputi bobot hidup, bentuk dan komposisi tubuh, termasuk perubahan komponen komponen tubuh seperti otot, lemak, protein dan abu (Soeparno, 1998). Purbowati (2009) menyatakan bahwa suatu individu erat kaitannya dengan perkembangan dimana perkembangan adalah perubahan bentuk suatu konformasi tubuh, termasuk perubahan struktur tubuh, perubahan kemampuan dan komposisi. Selama pertambahan bobot badan seekor ternak ada dua hal yang terjadi, yaitu (1) bobot badannya meningkat sampai mencapai 
Jurnal Sains Peternakan

Vol 7 No 1, Juni 2019, 62-69

ISSN 2579-4450

bobot badan dewasa, yang disebut pertumbuhan dan (2) terjadinya konformasi dan bentuk tubuh serta berbagai fungsi dan kesanggupannya untuk melakukan sesuatu menjadi wujud penuh yang disebut perkembangan. Perubahan bentuk tubuh atau dalam hal pertambahan bobot badan sangat berguna untuk seleksi pada pemuliaan ternak sebagai petunjuk dalam performans kondisi pada "grazing" atau feedlot, meskipun demikian yang penting bahwa makin mendekati dewasa tubuh pertambahan bobot badan semakin rendah (Wello, 2007).

Penelitian ini bertujuan untuk mengetahui pengaruh berat badan induk terhadap berat lahir pedet pada sapi Bali yang dipelihara secara semi-intensif. Dengan demikian penelitian ini dapat berguna sebagai bahan informasi bagi peneliti, peternak, dan masyarakat umum dalam upaya pengembangan ternak sapi Bali terutama aspek reproduksi.

\section{Materi Dan Metode}

Adapun materi penelitian ini yaitu menggunakan sapi Bali yang terdiri dari: 30 ekor induk berumur 3 - 5 tahun dan 30 ekor Pedet umur 1 hari yang dipelihara di Dinas Peternakan Kabupaten Belu, Provinsi Nusa Tenggara Timur. Data dikumpulkan mulai dari tahun 2015 2017 berdasarkan data recording dan pengamatan langsung.

Metode yang digunakan dalam penelitian ini adalah metode kuantitatif dan dianalisis dengan menggunakan Rancangan Acak Lengkap. Penelitian ini terdiri dari 3 perlakuan yaitu P1 bobot badan induk 151 - $200 \mathrm{Kg}$, P2 bobot badan induk $201-250 \mathrm{Kg}$, P3 bobot badan induk 251 - $300 \mathrm{Kg}$, masing - masing perlakuan diulang $10 \mathrm{kali}$.

Variabel yang diamati dalam penelitian ini adalah berat lahir dan pertambahan bobot badan pedet yang merupakan hasil penimbangan dari pedet yang baru lahir. Berat lahir diperoleh dengan menimbang anak sapi paling lambat 1 hari (24 jam) setelah lahir. Pengukuran berat lahir pedet dilakukan dengan menimbang pedet yang baru dilahirkan oleh ternak dengan menggunakan timbangan digital.

Data yang diperoleh dianalisis menggunakan analisis varian. Apabila perlakuan berpengaruh nyata maka dilakukan uji lebih lanjut dengan menggunakan BNT (Beda Nyata Terkecil) untuk membedakan pengaruh antar perlakuan.

\section{Hasil Dan Pembahasan}

\section{Berat Lahir Sapi Bali}

Berat lahir merupakan faktor yang penting dalam pertumbuhan pedet sapi. Sapi dengan berat lahir yang besar dan lahir secara normal akan lebih mampu mempertahankan 
Jurnal Sains Peternakan

Vol 7 No 1, Juni 2019, 62-69

ISSN 2579-4450

kehidupannya. Berdasarkan analisis ragam yang menunjukkan bahwa bobot badan induk tidak berpengaruh yang nyata terhadap berat lahir pedet $(\mathrm{P}>0,05)$. Seperti yang telah dinyatakan oleh Muzani (2004) bahwa beberapa faktor yang mempengaruhi bobot lahir antara lain induk, bangsa, genetik, jenis kelamin pedet, lama kebuntingan, umur induk dan berat induk. Azzam dan Neilsen (2008) juga menerangkan bahwa faktor-faktor yang berpengaruh terhadap bobot lahir antara lain adalah bangsa induk dan jenis kelamin pedet. Sedangkan dengan hasil penelitian Karnaen dan Arifin (2010), yang menyatakan bahwa masa kelahiran menunjukkan pengaruh terhadap berat lahir anak sapi (pedet) dengan kata lain berat lahir antara periode kelahiran yang satu dengan yang lain berbeda nyata. Rataan Berat Lahir, pedet sapi Bali yang dipelihara secara semi-intensif disajikan pada tabel 1.

Tabel 1. Rataan Berat Lahir pedet sapi Bali yang dipelihara secara semi-intensif

Perlakuan

Berat Lahir (Kg)

P1 (151-200)

P2 (201-250)

P3 (251-300)
$17,27 \pm 1,33$

$16,96 \pm 1,58$

$17,36 \pm 1,69$

Dari Tabel 1. di atas dapat dilihat rataan berat lahir dari induk yang berbeda yaitu, $\mathrm{P} 1$ dengan bobot badan induk 151-200 Kg dengan rataan 17,27 $\pm 1,33 \mathrm{Kg}$, P2 dengan bobot badan induk 201-250 Kg dengan rataan 16,96 \pm 1,58 Kg, P3 dengan bobot badan induk 251$300 \mathrm{Kg}$ dengan rataan 17,36 $\pm 1,69 \mathrm{Kg}$. Hal ini menunjukkan bahwa P3 dengan bobot badan induk 251-300 $\mathrm{Kg}$ memperlihatkan induk yang baik atau unggul akan menghasilkan keturunan yang baik pula. Sementara rataan bobot lahir yang diperoleh adalah 17,36 $\pm 1,69$ $\mathrm{Kg}$ di karenakan pedet yang di lahirkan oleh induk dengan berat 251-300 Kg rata-rata menghasilkan pedet yang berkualitas sedangkan induk dengan berat 150-200 Kg dan induk dengan berat 201-250 Kg rata-rata menghasilkan pedet yang kurang berkualitas, hasil ini tidak berbeda jauh dengan yang diperoleh dari penelitian Sarry (2012), yang dilakukan dari 2002 - 2012 di Dinas Peternakan Kabupaten Belu, rataan bobot lahir sapi Bali 20,5 Kg. Angka ini lebih tinggi dari penelitian Sumbung dkk, (2000), hasil penelitian yang dilakukan dari tahun 1998- 2000 di Dinas Peternakan Kabupaten Belu, rataan bobot lahir sapi Bali 18,64 Kg. Sutan (2004) menyatakan bahwa ada beberapa hal yang mempunyai hubungan dan mempengaruhi bobot lahir antara lain bangsa induk (betina/pejantan), jenis kelamin anak, lama bunting induk, umur atau paritas induk dan makanan induk sewaktu mengandung. 
Selain itu tingginya rata-rata berat lahir yang diperoleh karena adanya perbaikan manajemen dan pakan.

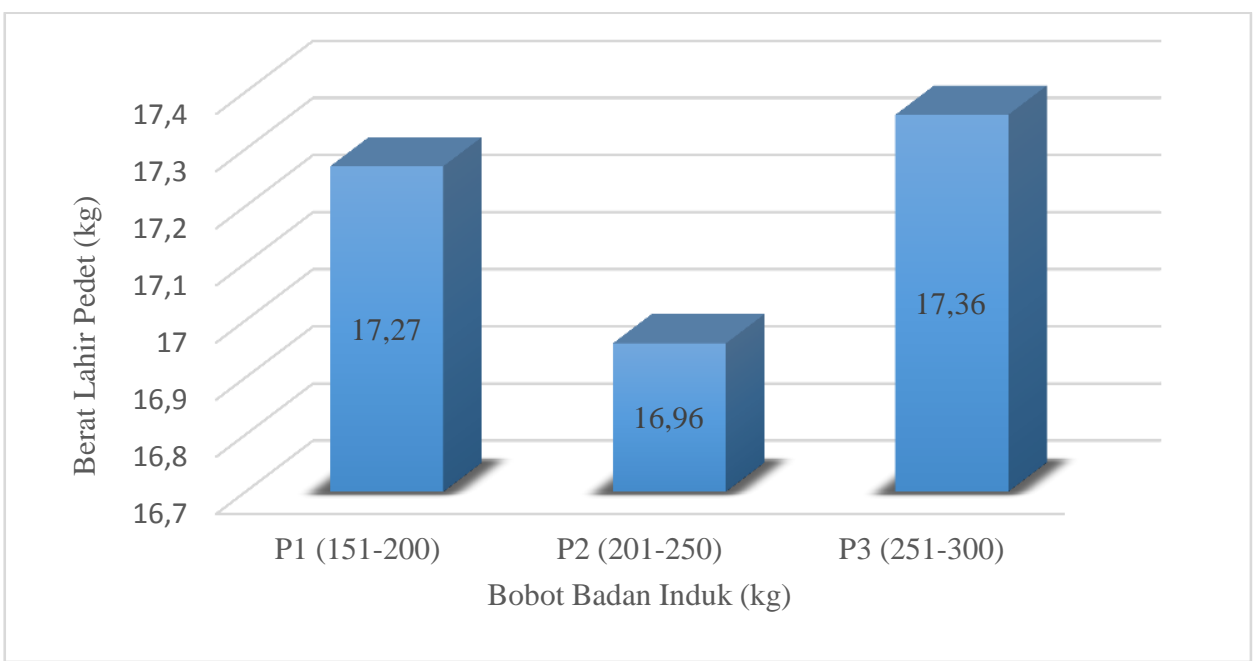

\section{Pertambahan Bobot Badan}

Gambar 2. Grafik bobot badan induk sapi Bali yang berbeda dengan umur yang sama

Pertumbuhan ternak biasanya dinyatakan dengan adanya perubahan bobot hidup, perubahan tinggi atau panjang badan. Makin berat kenaikan bobot badan perhari makin baik pertumbuhannya. Secara genetik pertumbuhan dibatasi sampai dewasa tubuh. Pola pertumbuhan ternak tergantung pada pola sistem manajemen yang dipakai, tingkat nutrisi yang tersedia, kesehatan dan iklim. Pertumbuhan dapat dinyatakan dengan pengukuran kenaikan bobot badan, yaitu dengan penimbangan berulang-ulang dan dibuat dalam pertambahan bobot harian, mingguan atau per satuan waktu yang lainnya (Tillman, 1991).

Santosa (2003) menyatakan bahwa setelah pedet lahir pertumbuhan menjadi semakin cepat hingga usia penyapihan. Dari usia penyapihan hingga puberitas laju pertumbuhan masih bertahan pesat, tetapi dari usia puberitas hingga usia jual laju pertumbuhan mulai menurun dan terus menurun hingga usia dewasa, akhirnya pertumbuhan terhenti.

Berikut data pertambahan bobot badan harian yang tertera pada tabel 2

Table 2. Data Pertambahan Bobot Badan Harian (PBBh

\begin{tabular}{lr}
\hline Perlakuan & Rataan \pm SD(Kg) \\
\hline P1(151-200) & $0,73 \pm 0,27 \mathrm{Kg}$ \\
P2(201-250) & $0,73 \pm 0,20 \mathrm{Kg}$ \\
P3(251-300) & $0,87 \pm 0,18 \mathrm{Kg}$ \\
\hline
\end{tabular}

Keterangan: Data pertambahan bobot badan harian diperoleh dari hasil pengurangan antara pertambahan bobot badan akhir dikurangi dengan bobot awal 
Dari Tabel 2. Diatas dapat dilihat rataan pertambahan bobot badan harian pedet dari induk yang berbeda yaitu, P1 dengan pertambahan bobot badan harian pedet dengan rataan $0,73 \pm 0,27 \mathrm{Kg}, \mathrm{P} 2$ dengan pertambahan bobot badan harian pedet dengan rataan $0,73 \pm 0,20$ $\mathrm{Kg}, \mathrm{P} 3$ dengan pertambahan bobot badan harian pedet dengan rataan $0,87 \pm 0,18 \mathrm{Kg}$. Hal ini menunjukan bahwa P3 dengan pertambahan bobot badan harian pedet dengan rataan (PBBH) $0,87 \pm 0,18 \mathrm{Kg}$ memperlihatkan pedet yang baik atau unggul.

Berdasarkan Tabel 2 terlihat bahwa P3 memiliki pertambahan bobot badan cenderung lebih tinggi dibanding dengan perlakuan P1 dan P2 meskipun berdasarkan analisisi ragam berat badan induk tidak berpengaruh nyata terhadap pertambahan bobot badan pedet $(\mathrm{P}>0,05)$. Pertumbuhan pedet dapat dilihat dari beberapa faktor salah satunya adalah berat lahir pedet dan pertambahan bobot badan harian, pedet yang mempunyai bobot lahir yang besar akan memberikan kenaikan yang besar pada pertambahan bobot badan. Hasil ini tidak berbeda jauh dengan yang dikemukakan oleh Parakkasi (1999), setiap peningkatan satu Kg bobot badan lahir akan meningkatkan rata-rata pertambahan bobot badan sebanyak 0,012 Kg. Sutan (2004) menyatakan bahwa ada beberapa hal yang mempunyai hubungan dan mempengaruhi bobot lahir antara lain bangsa induk (betina/pejantan), jenis kelamin anak, lama bunting induk, umur atau paritas induk dan makanan induk sewaktu mengandung.

\section{Kesimpulan}

Berdasarkan hasil penelitian maka dapat disimpulkan bahwa bobot badan induk tidak memberikan pengaruh yang nyata terhadap berat lahir dan pertambahan bobot badan pedet pada sapi Bali yang dipelihara secara semi-intensif.

\section{DAFTAR PUSTAKA}

Anonim. 2007. Pengantar Peternakan Hewan. Buku bahasa inggris masyarakat. Diakses pada 11 September 2015.

Abidin, Z. 2002. Kiat Mengatasi Permasalahan Praktis Penggemukan Sapi Potong. Agromedia Pustaka. Jakarta.

Astuti, M. 2004. Pemuliaan Ternak, Pengembangan dan Usaha Perbaikan Genetik Ternak Lokal. Pidato Pengukuhan Guru Besar dalam Ilmu Pemuliaan Ternak pada Fakultas Peternakan Universitas Gadjah Mada. Yogyakarta.

Caturto. 2007. Pemuliaan dan Tata laksana pemeliharaan ternak sapi. Penebar swadaya. Jakarta. 


\section{Jurnal Sains Peternakan}

Vol 7 No 1, Juni 2019, 62-69

ISSN 2579-4450

Darmadja, S.G.N.D. 2003. Setengah abad peternakan sapi tradisional dalam ekosistem pertanian di bali. Disertasi. Universitas Padjajaran. Bandung.

Pane, I. 2000. Upaya meningkatkan mutu genetik sapi Bali di P3 Bali. Pros. Seminar Nasional Sapi Bali 20-22 September. hlm: A42.

Prasojol, G. Arifiantini, I. Dan Mohamad, K. 2010. Korelasiantara lama

kebuntingan, bobot lahir dan jenis kelamin pedet hasil inseminasi buatan pada sapi Bali. Institut Pertanian Bogor. Bogor

Prakkasi, A. 1999. Ilmu makanan dan Ternak Ruminansia. UI Press, Jakarta

Purbowati, E. 2009. Pertumbuhan dan Perkembangan Ternak Potong dan Kerja. htt://id.scribd.com/.86474629/Pertumbuhan-Dan-an Diakses tanggal 10 Oktober 2015.

Rianton, E. dan Purbowati, E. 2009. Sapi Potong Penebas Swadaya Jakarta.

Rianto, E. dan Purbowati, E. 2011. Panduan Lengkap Sapi Potong. Cetakan 3, Swadaya, Jakarta.

Putu, I-G., P. Situmorang, P. Lubis, T.D. Chaniago, E. Triwulaningsih, T.

Santosa, U. 2003. Tatalaksana Pemeliharaan Ternak Sapi. Seri Agribisnis, cetakan IV. Penebar Swadaya, Jakarta.

Sugiarti, I-W. Mathius dan B. Sudaryanto. 2008. Pengaruh pemberian pakan konsentrat tambahan selama dua bulan sebelum dan sesudah kelahiran terhadap performan produksi dan Reproduksi Sapi Potong. Pros. Seminar Nasional Peternakan dan Veteriner. Bogor 1-2 Desember 2008. Puslibang Peternakan, Bogor. hlm. 279286.

Sumbung, F. P., J. T. Batosama, B. R. Ronda dan S. Garantjang. 2000. Performans Reproduksi Sapi Bali. Prosiding Seminar Ruminansia Besar. Direktorat Jenderal Peternakan dan Fakultas Peternakan IPB. Bogor.

Siregar. 2006. Aplikasi Pemuliabiakan Ternak Di Lapangan. PT. Gramedia Widia sarana Indonesia. Jakarta.

Sutan, SM. 2004. Perbandingan performans reproduksi dan produksi antara sapi Brahman, peranakan Ongole dan Bali didaerah transmigrasi Batumarta, Sumatra selatan. Disertasi. Intitut Pertanian Bogor. Bogor.

Tanari, M. 2001. Usaha pengembangan sapi Bali sebagai ternak lokal dalam menunjang pemenuhan kebutuhan protein asal hewani di Indonesia. http:// rudyct.250x.com/sem1_012/m_tanari. 


\section{Jurnal Sains Peternakan}

Vol 7 No 1, Juni 2019, 62-69

ISSN 2579-4450

Tilman, D., H. Hartadi, S. Reksohadiprodjo, S. Prawirokusumo dan S. Lebdosoekojo., 1991. Ilmu Makanan Ternak Dasar. Gadjah Mada university Press, Yogyakarta.

Trikesowo, N. Sumardi dan Suyadi. 2002. Kebijakan riset di bidang pengembangan dan perbaikan mutu sapi potong dengan teknik ladang ternak dan feedlot. Forum komunikasi hasil penelitian bidang peternakan, Yogyakarta.

Wello, B. 2011. Manajemen Ternak Sapi Potong. Masagena Press. Makassar.

Yasin S, Dilaga SH. 1993. Peternakan Sapi Bali dan Permasalahannya BumiAkasara, Jakarta

Yulianto, P dan Saparinto, C. 2010. Pembebasan Sapi Potong Secara Intensif Penebar, Jakartan. 